\title{
Creation of a national landslide domain map to aid susceptibility mapping in Great Britain
}

\author{
Claire Dashwood, Catherine Pennington, Emma Bee, Katy Freeborough, Tom Dijkstra
}

\begin{abstract}
The need to develop a national map that characterises landslides across Great Britain has long been recognised by the British Geological Survey as part of its strategic role providing hazard information to stakeholders. Hierarchical landslide domains represent areas of similar physiographic, meteorological, climatic and geological characteristics that shaped the style of landsliding. Developed to underpin current research into how different types of landslides and terrains will be affected by changing environmental conditions, the map further assists development of a national landslide susceptibility map with conditioning factors tailored to a specific domain.

This paper considers the role of national-scale land systems mapping to create a Landslide Domain Map, the refinement of a national model using landslide inventories to better reflect the spatial extent and characteristics of landslides within domains. The distribution of landsliding in Great Britain is a product of the complex range of lithologies and geomorphological processes active under a range of climatic conditions. The domains represent landslides across a series of unstable slopes ranging from very large, ancient landslides formed under periglacial climate conditions to small, modern failures, particularly along transport infrastructure corridors. Although analysis of the National Landslide Database broadly informed the nature of landsliding within a specific domain, expert knowledge was needed to supplement it especially in areas where recent mapping had not taken place. Targeted data collection is planned in data-poor domains to supplement the database. Further domain-specific research is ongoing and includes development of semi-empirical process-specific models involving the weighting of critical factors in order to refine the current national landslide susceptibility map, GeoSure. As an example of this refinement, this paper discusses an improved debris flow model for the Scottish Highlands.
\end{abstract}

\section{Keywords}

Landslide Domains Map, landslide inventory, susceptibility mapping, debris flows

\section{Introduction: Landsliding in Great Britain}

The British Geological Survey (BGS) continuously captures landslide data in the National Landslide Database (NLD; Foster et al. 2012) at national, regional and site-specific scales for both new and historic events in Great Britain with the aim of improving the knowledge of landslide processes and their spatial and temporal distribution. Many of the landslides recorded in the NLD are ancient and inactive. However, periods of high rainfall accumulation have resulted in an increase in landslide activity, with recent examples including the summer of 2012 and the winters of 201213, 2013-14 and 2015-16. Many of the landslides triggered during these periods were relatively small, but their impacts have been significant (e.g. causing fatalities in Burton Bradstock and Beaminster in 2012; and in Looe in 2013; Pennington and Harrison, 2013; Pennington et al. 2014; Pennington et al. 2015). These events have reinforced the importance of recording detailed information (in particular accurate location and time of occurrence) in the NLD, enabling further development of national scale landslide susceptibility and hazard assessments (e.g. Reeves et al. 2012; Hurst et al. 2013; Gibson et al. 2013; Pennington et al. 2014; Dijkstra et al. 2016).

Despite continued data collection and targeted regional mapping campaigns, there are still large areas of Great Britain where landslide events have not yet been recorded. This incomplete dataset continues to affect regional and national landslide susceptibility and hazard assessments. The development of landslide domains attempts to provide a means to 'fill in the gaps'. 
Previous approaches to the division of Great Britain into landslide terrain units, or domains have focussed primarily on the pattern of landsliding with respect to geology (e.g. Jones and Lee 1994; Cooper 2007), but although this highlighted typical landslide-prone bedrock formations, it did not enable differentiation in terms of type, scale or frequency of landsliding. The Landslide Domain project aims to address this by using a wide range of national-scale information held at the BGS. All references to landslide type refer to the new nomenclature as defined by Hungr et al. 2014.

\section{Land Systems Mapping}

The development of the Landslide Domain Map incorporated a land system mapping method (Engineering Group Working Party 1982; Griffiths et al. 2005; Guzzetti 2005; Pasuto and Soldati 1999; Savigear 1965; Styles et al. 1984; Wilshusen 1979). A terrain system covering a large area can be subdivided into a number of defining terrain facets, which in turn may be further broken down to terrain elements (Tab. 1).
Tab. 1 Characteristics of the three land system mapping units (after Phipps 2001; Engineering Group Working Party 1982). Mappable scales are approximate.

\begin{tabular}{|l|l|l|l|}
\hline $\begin{array}{l}\text { Terrain } \\
\text { Unit }\end{array}$ & $\begin{array}{l}\text { Mappable } \\
\text { Scale }\end{array}$ & Definable By & Example \\
\hline $\begin{array}{l}\text { Land } \\
\text { System }\end{array}$ & $\begin{array}{l}\text { 1:100o,ooo- } \\
1: 250,000\end{array}$ & $\begin{array}{l}\text { Vegetation, } \\
\text { land use, } \\
\text { dissection, } \\
\text { soil, } \\
\text { topography }\end{array}$ & $\begin{array}{l}\text { Upland } \\
\text { Granite } \\
\text { moor }\end{array}$ \\
\hline $\begin{array}{l}\text { Land } \\
\text { Facet }\end{array}$ & $\begin{array}{l}\text { 1:60,ooo- } \\
1: 10,000\end{array}$ & $\begin{array}{l}\text { Homogenous } \\
\text { parent } \\
\text { material, } \\
\text { single water } \\
\text { regime, slope } \\
\text { angle }\end{array}$ & $\begin{array}{l}\text { Hill, } \\
\text { terrace, } \\
\text { valley }\end{array}$ \\
\hline $\begin{array}{l}\text { Land } \\
\text { Element }\end{array}$ & $\begin{array}{l}\text { Map in } \\
\text { field } \\
\text { directly }\end{array}$ & $\begin{array}{l}\text { Slope } \\
\text { Floodplain, } \\
\text { dip slope }\end{array}$ \\
\hline
\end{tabular}

Table 1 Data sources used for the Landslides Domain Map

\begin{tabular}{|c|c|c|}
\hline Data Source & Description & Available Scales \\
\hline Geological Maps & $\begin{array}{l}\text { Bedrock geology, superficial deposits, artificial ground, linear } \\
\text { features such as faults and mass movement deposits (Smith, 2013) }\end{array}$ & $\begin{array}{l}1: 10000 \\
1: 25000 \\
1: 50 \text { ooo }\end{array}$ \\
\hline $\begin{array}{l}\text { Engineering } \\
\text { Geological Map }\end{array}$ & $\begin{array}{l}\text { The Engineering Geology Map of the UK reassesses each of the } \\
\text { lithostratigraphical bedrock units and lithogenetic superficial } \\
\text { deposits on dominant lithology and characterises it by geotechnical } \\
\text { properties and engineering behaviour (Dobbs et al. 2012). }\end{array}$ & 1:1 000 ooo \\
\hline $\begin{array}{l}\text { National Landslide } \\
\text { Database }\end{array}$ & $\begin{array}{l}\text { The most comprehensive source of information on landslides in } \\
\text { Great Britain, currently holds records of over 17,0oo landslide } \\
\text { events (Foster et al. 2012; Pennington et al. 2015). }\end{array}$ & $\begin{array}{l}\text { First-hand field } \\
\text { observations to } \\
\text { 1:50 ooo }\end{array}$ \\
\hline GeoSure & A national map of landslide susceptibility on inland, natural slopes. & 1: 50000 \\
\hline $\begin{array}{l}\text { Quaternary Domain } \\
\text { Map }\end{array}$ & $\begin{array}{l}\text { A subdivision of Great Britain into glaciated and non-glaciated } \\
\text { terrain refined into eleven domains reflecting geomorphological } \\
\text { features, assemblages of superficial deposits and surface processes. }\end{array}$ & 1:1 000 ooo \\
\hline Aerial photographs & $\begin{array}{l}\text { Aerial photographic interpretation at BGS is currently carried out } \\
\text { using SOCETSET }{ }^{\mathrm{TM}} \text {, a digital photogrammetry software package } \\
\text { used to view orthorectified aerial photographs in stereo. }\end{array}$ & $25 \mathrm{~cm}$ \\
\hline $\begin{array}{l}\text { Ground-based } \\
\text { photographs }\end{array}$ & $\begin{array}{l}\text { Conventional photography, including the BGS's image archive } \\
\text { 'ImageBase', has been utilised for local detail where required. }\end{array}$ & Ground based \\
\hline Topography Maps & Ordnance Survey topographic maps & $\begin{array}{l}1: 1250- \\
1: 1000 \text { ooo }\end{array}$ \\
\hline DTM (NextMap $\left.{ }^{\mathrm{TM}}\right)$ & $\begin{array}{l}\text { NextMap }{ }^{\mathrm{TM}} \text { images, a digital terrain model, produced by Intermap } \\
\text { from airborne Interferometric Synthetic Aperture Radar, proved } \\
\text { useful for delineating topographic areas as well as creating maps for } \\
\text { slope angle and relief which could be used to create terrain units. }\end{array}$ & $25 \mathrm{~m}$ \\
\hline $\begin{array}{l}\text { Expert local geological } \\
\text { knowledge }\end{array}$ & $\begin{array}{l}\text { Expert local geological knowledge from BGS field mappers (where } \\
\text { available) to provide clarification of details of lithostratigraphical } \\
\text { and structural features and their influence on slope stability. }\end{array}$ & $\begin{array}{l}\text { First-hand field } \\
\text { observation }\end{array}$ \\
\hline
\end{tabular}


Following this approach, we defined terrain units based on interrelations between material, forms and processes resulting in boundaries that reflect areas of geomorphological and geological similarity.

This style of land system mapping and definition of terrain units is useful for the assessment of landslides because it allows large areas to be classified quickly providing a useful regional picture for data collection and storage. The land system mapping approach has been used successfully at the BGS to create maps of Quaternary Domains (Booth et al. 2012), Till Domains (Entwisle and Wildman, 2010) and Hydrogeological Domains in a framework of ${ }_{3} \mathrm{D}$ geological models (McMillan et al. 200o).

\section{Resources}

Determining which resources would be best utilised to enable creation of the landslide domain map focused on the identification of the most important controls on landslide distribution and occurrence. Highland and Bobrowsky (2008), Reeves et al. (2012), Hurst et al. (2013), Gibson et al. (2013), Pennington et al. (2014) and Dijkstra et al. (2016) identify a number of these controls such as relief, morphology of the terrain as well as the soil and underlying geology. BGS data including national scale geological maps coupled with geomorphological and geological expertise, and the analysis of the landslide database, supports these broad observations and has resulted in the selection of a range of resources that contributed to the creation of the landslides domain map (Table 2).

The Landslide Domain Map of Great Britain

The Landslide Domain Map (Fig. 1) of Great Britain comprises six large domains (system scale), which are broadly defined by landslide type and replicate patterns in geological conditions and topography. Smaller scale sub-domains (facet scale) provide more detail and resolution on the type of movement, placing greater emphasis on geology, slope and geomorphological processes.

The domains are as follows:

1. Isolated landslide events: Gently undulating lowrelief landscapes associated with isolated valley side rotational and planar landslides.

2. Small scale shallow rotational, translational landslides and debris flows: Shallow rotational, planar landslides and debris flows in bedrock and superficial material. Contemporary landsliding and reactivation of relict failures. Predominantly controlled by localised steeper slopes where there is sufficient material to fail.These types of landslides usually occur as single events or clusters and are ubiquitous across GB.

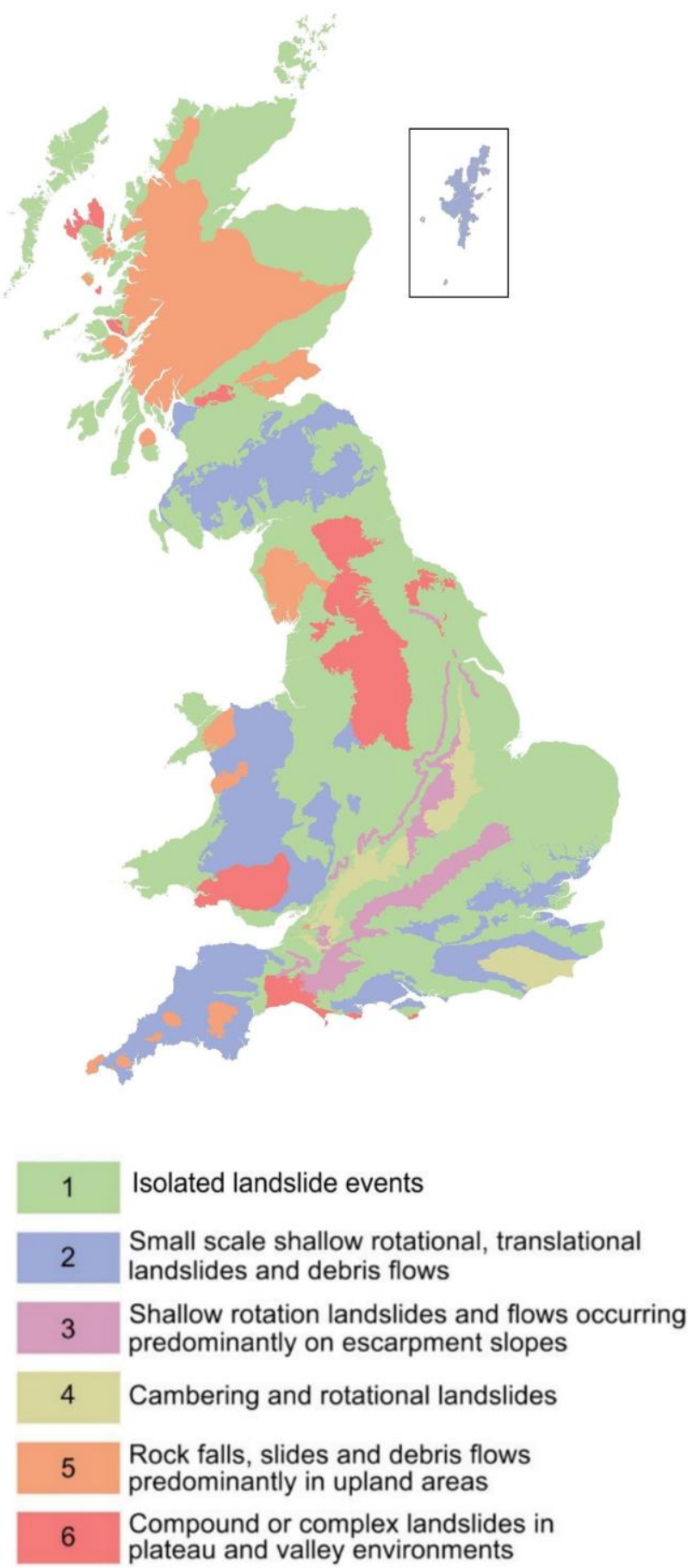

Fig. 1 The Landslide Domain Map of Great Britain. BGS (C) NERC 2016. All rights reserved. Contains Ordnance Survey data (coastline) (C) Crown copyright and database right 2016 . 
3. Shallow rotational landslides and flows occurring predominantly on escarpment slopes: Shallow rotational landslides and flows occurring predominantly on escarpment slopes.

4. Cambering and rotational landslides: Cambering and rotational landslides involving clayrich bedrock overlain by a hard cap rock.

5. Rock falls, slides and debris flows predominantly in upland areas: Falls, slides, rock slope deformations and debris flows in hard rock environments. Paraglacial rock processes occurring.

6. Compound or Complex landslides in plateau and valley environments: Complex or compound landslides comprising rotational and translational landslides, often degrading into flows, in plateau and valley landscapes. These landslides are typically larger and have a longer run out than similar landsldies in other domains. Although smaller events may be widespread in these areas large scale landslides are the most characteristic due to their scale.

Refining the National Landslide Susceptibility Map using Domain specific characteristics- A case study of landslide types and processes in Domain 5.

Landslide Domain 5 (Figs. 1 \& 2) extends across the upland area of Scotland, Fife, the Lake District, Snowdonia National Park and the igneous intrusions of Devon and Cornwall and there are, at the time of writing, over 1100 recorded landslides held in the NLD for this domain. The domain incorporates a wide range of geological and geomorphological landscapes that have been shaped by Quaternary processes that are still evident through the remnant steep slopes, cirques, fjords and lochs. The steep, upland areas are prone to debris flows, rock falls and avalanches as well as nonrotational rock slope deformations associated with quartzose mica-schist bedrock and particularly where intense periglacial weathering and paraglacial rock processes have resulted in surface materials more prone to landsliding.

In Scotland, Domain 5 is defined by the presence of large-scale rock slope deformations and debris flows, the location of which are particularly prevalent on glacially steepened slopes (Fig. 2 and examples given in Fig. 3). A subdivision of the domain was based on the presence and intensity of debris flow activity on steep slopes overlying granites and where rock slope deformations were less prevalent on the sandstones (classified as sub-domain 5.3). This sub-division is supported by observational data (e.g. Ballantyne 2004; Ballantyne et al. 2014; Jarman 2006; Strachan 2015).
The Rest and Be Thankful (RaBT) area (Fig 2) is sited within sub-domain 5.3. For the small RaBT area the NLD contains data on 35 debris flows. Despite significant similarities in geology and geomorphology, sub-domain 5.3 only has data for a total of 80 debris flow events. This suggest some $40 \%$ of debris flow events occur in an area covering less than $1 \%$ of the whole domain and this clearly indicates that a substantial number of debris flow events remained unrecorded.

Information gathered during the generation of the domain map enabled identification of areas likely to be susceptible to debris flow occurrence. An aerial photograph interpretation exercise was carried out to produce a more complete debris flow map, which identified more than 1100 additional debris flow locations in this domain. This new debris flows inventory was compared to GeoSure and it became apparent that this type of failure is not always identified by the current methodology. Work was undertaken to improve the method of identifying areas debris flows susceptibility based on a modification of the GeoSurestyle approach. Previously work had been carried out by BGS in conjunction with TRL on a debris flow model for Transport Scotland produced in 2005, was focussed on trunk roads (Winter et al., 2005). Published literature and an analysis of the expanded debris flow inventory provided a set of criteria that could be assessed to identify slopes susceptible to debris flows. These criteria included slope angle, permeability, parent material, quaternary processes and presence of stream channels.

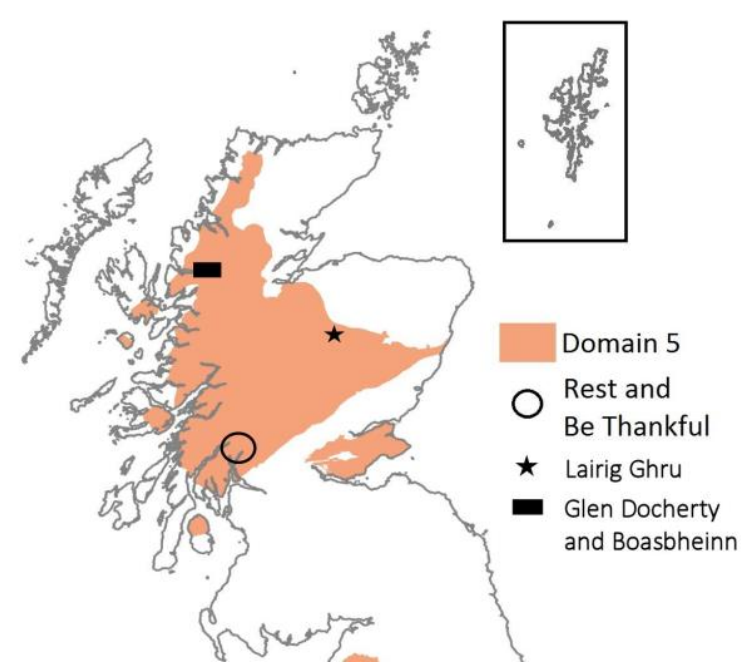

Fig. 2 Domain 5 in Scotland. BGS (C) NERC 2016. All rights reserved. Contains Ordnance Survey data (coastline) (c) Crown copyright and database right 2016. 
Literature on debris flows, supported by the debris flow inventory, produced a well-defined set of slope angles within which debris flow activity is usually induced which were different to those currently used to assess landslide susceptibility. The majority of debris flows in Scotland occur between 30-46 degrees (Ballantyne, 1982, 2004; Heald and Parsons 2005; Innes 1983; Milne 2008) which is much steeper than the shallow translational landslides that occur on Eocene clays in the South East of England for example. A maximum slope angle was introduced into the model to take into account the steepest angle that debris on a slope is likely to accumulate at and therefore be available for failure as a debris flow (Winter et al., 2005).

The presence of stream channels derived from a DTM was included as a contributing factor so that the influence of these channels on the entrainment of debris and the concentration of water could be taken into account- reflecting the presence of both open slope and valley confined debris flows in Scotland (Ballantyne, 2004). Debris flows in Scotland are commonly triggered by heavy rainfall leading to a build up of pore water pressures within slope material that leads to failure. The rate at which water can infiltrate into a slope and subsequently increase pore water pressures is higher in coarse grained sediments such as the weathered products of sandstone or granite as well as Quaternary deposits such as Till. The permeability of the upper $3 \mathrm{~m}$ of material was included as a component in the assessment to determine the ability of the slope deposits to drain freely into the underlying material. The assumption being that if the underlying material was less permeable than water would infiltrate more slowly and this could contribute to increased pore pressures.

To identify those slope deposits more susceptible to debris flows the Parent Material Map of Great Britain was used. Parent material is defined as a geological deposit over, and within which, a soil develops and represents the near surface geology. The Parent Material Map contains information within it on the distribution of fine material versus coarse material in the parent material in its weathered state. Those deposits that consist of coarse grained, cohesionless material would be more susceptibility to debris flows and are weighted more highly within the model. To supplement the topographic and geological information used during the creation of the model the Quaternary history of an area and the influence of this on the landforms was taken into account. As a tool to assess glacial and periglacial deposits and landforms in Great Britian BGS created a Quaternary Domain Map which subdivided Great Britain into 11 domains reflecting geomorphological features, assemblages of superficial deposits and surface processes across glaciated and unglactiated terranes (Booth et al., 2012). When viewed alongside the domain map the debris flow inventory reflected the lack of failures in the NW of Scotland where glacial scouring of slopes was most severe and where it is likely that sediments and weathering products on these slopes had already been removed by glacial processes. It is unlikely that there would be a sufficient thickness of material present on slopes in this area to fail as a debris flow and the Quaternary domain map was used to downgrade slopes previously subjected to intense scouring activity. Each of the factors within the individual component layers were assigned a score depending on their propensity to inhibit or promote instability. The factors were added together within a GIS and displayed on a 5 point scale reflecting low through to high susceptibility to debris flows (Figure 4). Further validation of the model through fieldwork and aerial photograph interpretation is intended to refine the model where appropriate. 

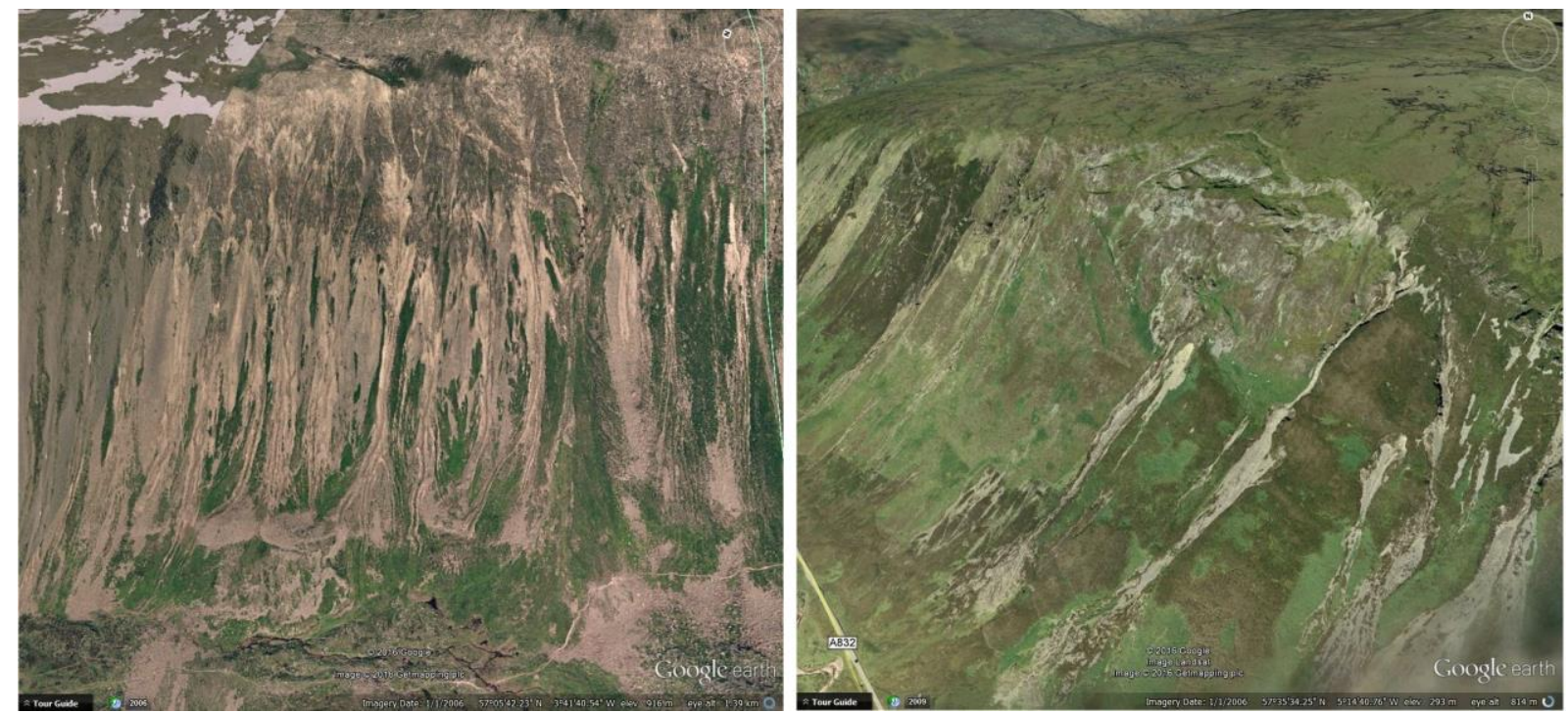

Fig. 3 Left: Debris flows in Lairig Ghru. Right: Rock slope deformation and debris flows in Glen Docherty, both in Domain 5. See Fig. 2 for locations; satellite images from Google Earth ${ }^{\mathrm{TM}}$ (Google and the Google logo are registered trademarks of Google Inc., used with permission).


Fig. 4 Debris flows, previously undocumented in the NLD, found using targeted aerial photograph interpretation. Blue dots: debris flows. Red and orange pixels: debris flow potential model. Left, Lairig Ghru; Right Boasbheinn, Scotland. See Fig. 2 for location map.

\section{Acknowledgments}

The authors would like to thank BGS staff: H Reeves, V Banks, A Harrison, H Jordan, K Lee, P Hobbs, G Jenkins, D Boon and A Patton. The authors publish with the permission of the Executive Director of the BGS (NERC).
References (in the alphabetical order)

Ballantyne, C K (2004) Geomorphological changes and trends in Scotland: debris flows. Scottish Natural Heritage Commissioned Report No. 052 (ROAME No. F00AC107A).

Ballantyne, C K, Sandeman, G F, Stone, J O, Wilson, P (2014) Rock-slope failure following Late Pleistocene deglaciation on tectonically stable mountainous terrain. Quaternary Science Reviews 86: 144-157. 
Booth, K A, Booth, S J, Slater, C (2012) BGS Geological Cross Sections and Quaternary Domains: User Guidance Note, British Geological Survey Report OR/10/030, Nottingham, UK, $36 \mathrm{pp}$.

Cooper, R G (2007) Mass Movements in Great Britain. Geological Conservation Review Series, 33. Joint Nature Conservation Committee, Peterborough, UK, 348 pp.

Dijkstra, T A, Jenkins, G, Gunn, D, Dashwood, C, Dankers, R, Dixon, N, Petley, D, Gibson, A, Winter, M G (2016) Landslides and climate change in the United Kingdom. In: JCT1: Joint Technical Committee on Natural Slopes and Landslides, TR3 Report. In press

Dobbs, M R, Culshaw, M G, Northmore, K J, Reeves, H J, Entwisle, D C (2012) Methodology for creating national engineering geological maps of the UK. Quarterly Journal of Engineering Geology and Hydrogeology 45, 335-347.

Engineering Group Working Party (1982) Land surface evaluation for engineering practice. Quarterly Journal of Engineering Geology 15, 265-316.

Entwisle, D C, Wildman, G (2010) Creation of the Till thematic Layer, British Geological Survey Report IR/10/041, Nottingham, UK, 9 pp.

Foster, C, Pennington, C V L, Culshaw, M G, Lawrie, K (2012) The National Landslide Database of Great Britain: development, evolution and applications. Environmental Earth Sciences 663, 941-953.

Gibson, A D, Culshaw, M G, Dashwood, C, Pennington, C V L (2013) Landslide management in the UK - the problem of managing hazards in a 'low risk' environment. Landslides 10, 599-610.

Griffiths, J S, Hart, A B, Mather, A E, Stokes, M (2005) Assessment of some spatial and temporal issues in landslide initiation within the Rio Aguas catchment, Southeast Spain. Landslides 2.

Guzzetti, F (2005) Landslide hazard and risk assessment: concepts, methods and tools for the detection and mapping of landslides, for landslide susceptibility zonation and hazard assessment, and for landslide risk evaluation, Friedrich-Wilhelms-Univestität, Bonn, Germany, $373 \mathrm{pp}$.

Heald, A, Parsons, J (2005) Introduction to landslide hazards. In: Winter, M G, MacGregor, F, Shackman, L (eds). Scottish Road Network Landslides Study. Scottish Executive. Edinburgh.

Highland, L M, Bobrowsky, P (2008) The Landslide Handbook- A guide to understanding landslides. US Geological Survey Circular 1315, 129 pp.

Hungr, O, Leroueil, S, Picarelli, L (2014) The Varnes classification of landslide types, an update. Landslides 11: 167-194.

Hurst, M D, Ellis, M A, Royse, K R, Lee, K A, Freeborough, $K$ A (2013) Controls on the magnitude-frequency scaling of an inventory of secular landslides. Earth Surface Dynamics 1, 97-78.
Innes, J L (1983) Debris flows. Progress in Physical Geograpy, 7: 469-501.

Jarman, D (2006). Large rock slope failures in the Highlands of Scotland: Characterisation, causes and spatial distribution. Engineering Geology 83(1-3): 161-182.

Jones, D K C, Lee, E M (1994) Landsliding in Great Britain. Department of the Environment, HMSO, London, UK, $361 \mathrm{pp}$.

Lee, K, Diaz Doce, D (2014) User Guide for the British Geological Survey GeoSure dataset, British Geological Survey Open Report: OR/14/012.

McMillan, A A, Heathcote, J A, Klinck, B A, Shepley, M G, Jackson, C P, Degnan, P J (2000) Hydrogeological characterization of the onshore Quaternary sediments at Sellafield using the concept of domains. Quarterly Journal of Engineering Geology and Hydrogeology 33, 301-323.

Milne, F D (2008) Topographic and material controls on the Scottish debris flow geohazard. PhD Thesis. University of Dundee.

Pasuto, A, Soldati, M (1999) The use of landslide units in geomorphological mapping: an example in the Italian Dolomites. Geomorphology 30, 53-64.

Pennington, C V L, Dijkstra, T A, Lark, M, Dashwood, C, Harrison, A M, Freeborough, K A (2014) Antecedent precipitation as a potential proxy for landslide incidence in SW UK. In: K. Sassa, P. Canuti, Y. Yin (Eds.), Landslide Science for a Safer Geoenvironment 1. Springer International Publishing, Switzerland, pp. 253-269.

Pennington, C V L, Freeborough, K A, Dashwood, C, Dijkstra, T A, Lawrie, K (2015) The National Landslide Database of Great Britain: acquisition, communication and the role of social media. Geomorphology Special Issue: Geohazard Databases: Concepts, Development, Applications, 249: 44-51.

Pennington, C V L, Harrison, A M (2013) 2012 - Landslide Year?, GeoScientist, pp. 10-15.

Phipps, P J (2001). Terrain systems mapping. In: Griffiths, J $S(E d$.$) , Land surface evaluation for engineering practice.$ Geological Society of London, London, UK, pp. 59-61.

Reeves, H J, Dashwood, C, Jordan, C, Dijkstra, T A (2012) Landslides in Great Britain: a novel, multi-stage national methodology for landslide mapping, inventory and susceptibility assessment. First International Symposium: New Techniques for Geohazards Research and Management, September 2012, Lanzhou, China.

Savigear, R A G (1965) A technique of morphological mapping. The Annals of the Association of American Geographers 55, 514-538.

Smith, A (2013) Digital geological map of Great Britain: information notes, British Geological Survey Open Report OR/13/007, Nottingham, UK, 54 pp.

Strachan, G J (2015) Debris flow activity and gully propagation: Glen Docherty, Wester Ross. Scottish Journal of Geology 51: 69-80. 
Styles, K A, Hansen, A, Dale, M J, Burnett, A D (1984) Terrain classification methods for development planning and geotechnical appraisal: a Hong Kong case. Proceedings of the 4th International Symposium on Landslides, Toronto, 2, 561-568.

Wilshusen, J P (1979). Geologic hazards in Pennsylvania, Pennsylvania Geological Survey, 56 pp.

Claire Dashwood $(\bowtie)$

British Geological Survey, Keyworth, Nottinghamshire. NG12 5HP, United Kingdom.

E-mail: cfoster@bgs.ac.uk

Catherine Pennington

British Geological Survey, Keyworth, Nottinghamshire. NG12 5HP, United Kingdom.

E-mail:cpoulton@bgs.ac.uk

Emma Bee

British Geological Survey, Keyworth, Nottinghamshire. NG12 5HP, United Kingdom.

E-mail: ebee@bgs.ac.uk

Kathryn Freeborough

British Geological Survey, Keyworth, Nottinghamshire. NG12 5HP, United Kingdom.

E-mail: karo@bgs.ac.uk

Tom Dijkstra

British Geological Survey, Keyworth, Nottinghamshire. NG12 5HP, United Kingdom.

E-mail: tomdij@bgs.ac.uk 